Ambiente \& Água - An Interdisciplinary Journal of Applied Science
ISSN 1980-993X - doi:10.4136/1980-993X
www.ambi-agua.net
E-mail: ambi.agua@gmail.com

\title{
Sorption of Remazol Black B dye in alluvial soils of the Capibaribe River Basin, Pernambuco, Brazil
}

\author{
ARTICLES doi:10.4136/ambi-agua.2491
}

Received: 05 Nov. 2019; Accepted: 19 Feb. 2020

\author{
Adriana Thays Araújo Alves ${ }^{1 *}$; ;uisa Thaynara Muricy de Souza Silva1 ${ }^{1}$; \\ Lucas Ravellys Pyrrho de Alcântara ${ }^{2}{ }^{\circledR}$; Vitor Hugo de Oliveira Barros ${ }^{3}{ }^{(D}$; \\ Severino Martins dos Santos Neto ${ }^{(D}$; Valmir Félix de Lima2 ${ }^{2}$; \\ José Romualdo de Sousa Lima ${ }^{4}$; Artur Paiva Coutinho ${ }^{1}$; \\ Antonio Celso Dantas Antonino 2 it
}

${ }^{\mathbf{1} N u ́ c l e o ~ d e ~ T e c n o l o g i a . ~ U n i v e r s i d a d e ~ F e d e r a l ~ d e ~ P e r n a m b u c o ~(U F P E), ~ A v e n i d a ~ M a r i e l l e ~ F r a n c o, ~ S / N, ~ K m ~ 59, ~}$ CEP: 55014-900, Caruaru, PE, Brazil. E-mail: luisataynara12@hotmail.com, arthur.coutinho@yahoo.com.br ${ }^{2}$ Departamento de Energia Nuclear. Universidade Federal de Pernambuco (UFPE), Avenida Professor Luiz Freie, $n^{\circ}$ 1000, CEP: 53740-545, Recife, PE, Brazil. E-mail: ravellyspyrrho@ gmail.com, martinsdsn@gmail.com, atrazina@gmail.com, acdantonino@gmail.com

${ }^{3}$ Instituto Federal do Sertão Pernambucano, Rodovia PE 320, S/N, km 126, Zona Rural, Caixa Postal 78, Serra Talhada, PE, Brazil. E-mail: vitor_barros1@outlook.com

${ }^{4}$ Unidade Acadêmica de Garanhuns. Universidade Federal Rural de Pernambuco (UFRPE), Avenida Bom Pastor, S/N, CEP: 555292-278, Garanhuns, PE, Brazil. E-mail: romualdo_solo@yahoo.com.br

*Corresponding author. E-mail: adrianathaaraujo@gmail.com

\section{ABSTRACT}

Wastewater from textile industries is loaded with synthetic dyes. These effluents are often not adequately treated, affecting the soil and groundwater quality and leading to environmental contamination. The Agreste mesoregion of the state of Pernambuco is home to one of the largest textile centers in Brazil. This work therefore aims to study the behavior of Remazol Black B (RB5) dye in subsurface mediums in this region. The kinetics and isotherm sorption experiments allowed an evaluation of RB5 retention capacity in two layers of alluvial soil of the dry riverbed of the Capibaribe Basin. The maximum sorption rate was $81.81 \mathrm{mg} \mathrm{kg}^{-1}$ and $21.7 \mathrm{mg} \mathrm{kg}^{-1}$ for the loamy sand and sand layers, respectively. The Pseudo-second order kinetic model described more appropriately the sorption kinetics for both soils. The isotherms behavior was nonlinear, and Freundlich model was the most suitable to describe this process for both soils, presenting $\mathrm{K}_{\mathrm{F}}$ values of $8.6407 \mathrm{~L} \mathrm{~kg}^{-1}$ for loamy sand and $0.1868 \mathrm{~L} \mathrm{~kg}^{-1}$ for sand. The isotherm parameters confirm a more significant interaction of RB5 with the loamy sand layer than with the sand layer, indicating lower leaching in the first layer, which is less mobile for RB5 contamination. Furthermore, the different sorption rates for both soils indicate the importance of studying the soil as a heterogeneous profile.

Keywords: isotherm, kinetics, mobility.

\section{Sorção de corante Remazol Black B em solos aluviais da Bacia do Rio Capibaribe Pernambuco, Brasil}

\section{RESUMO}

As águas residuais das indústrias têxteis são carregadas com corantes sintéticos. Esses 
efluentes geralmente não são tratados adequadamente, afetando a qualidade do solo e das águas subterrâneas, levando à contaminação ambiental. O Agreste de Pernambucano abriga um dos maiores centros têxteis do Brasil. Portanto, este trabalho tem como objetivo estudar o comportamento do corante Remazol Black B (RB5) em meios subsuperficiais nessa região. Os experimentos de cinética e sorção isotérmica permitiram avaliar a capacidade de retenção do RB5 em duas camadas de solo aluvial do leito seco do rio Capibaribe. A taxa máxima de sorção foi de $81,81 \mathrm{mg} \mathrm{kg}^{-1}$ e $21,7 \mathrm{mg} \mathrm{kg}^{-1}$ para a camada areia franco e camada areia, respectivamente. $\mathrm{O}$ modelo cinético de pseudo-segunda ordem descreveu mais adequadamente a cinética de sorção para ambos os solos. O comportamento das isotermas foi não-linear e o modelo de Freundlich foi o mais adequado para descrever esse processo para ambos os solos, apresentando valores de $\mathrm{K}_{\mathrm{F}}$ de $8,6407 \mathrm{~L} \mathrm{~kg}^{-1}$ para areia franco e $0,1868 \mathrm{~L} \mathrm{~kg}^{-1}$ para areia. Os parâmetros isotérmicos confirmam uma interação mais significativa do RB5 com a camada de areia franco do que com a camada de areia, indicando menor lixiviação na primeira camada, menos móvel para a contaminação por RB5. Além disso, as diferentes taxas de sorção para os dois solos indicam a importância do estudo do solo como um perfil heterogêneo.

Palavras-chave: cinética, isotérmica, mobilidade.

\section{INTRODUCTION}

The Agreste of the state of Pernambuco is inserted in the Brazilian semi-arid region, configuring a region marked by low rainfall, high evapotranspiration rates, and intermittent rivers with flow only in the rainy season (Braga, 2016). In the absence of surface water resources, many rural communities in this region use underground reservoirs, such as alluvial deposits, by digging wells in the dry riverbed (Braga et al., 2015).

These formations attract several anthropogenic activities, increasing the contamination risk of the alluvial deposits' water reserves. In this region of the Agreste of Pernambuco is concentrated the so-called "Textile Center", encompassing municipalities such as Santa Cruz do Capibaribe, Toritama, Caruaru and Brejo da Madre de Deus (SEBRAE, 2013). This activity has negative impacts due to the release of untreated effluents, which have caused severe environmental contamination problems in the region. Wastewater from these industries is a complex mix of dyes and heavy-metal compounds (Shalaby et al., 2017).

In textile manufacturing, the dyeing step is the most substantial process in terms of time, added value, and technical complexity (Huynh and Chien, 2018). This step includes the dyeing itself and the washing to remove the non-fiber dye, releasing 10 to $15 \%$ into wastewater (Jayanthy et al., 2014).

Kharat (2015), reported cases where the indiscriminate discharge of textile effluents has affected soil and groundwater quality. In this way, some synthetic dyes are soil pollutants that concern researchers due to the toxic nature and adverse effect on life forms (Smaranda et al., 2017). Regarding this, azo dyes are carcinogenic in nature (Jayanthy et al., 2014; Stagnaro et $a l ., 2015)$. This dye typology is characterized by having one or more double nitrogen bonds ($\mathrm{N}=\mathrm{N}-$ ) (Jayanthy et al., 2014), and approximately half of the world's industrial production belongs to this class (Stagnaro et al., 2015).

The intense textile activity in the Agreste of Pernambuco and the importance of conserving the scarce surface and groundwater in the region make necessary the development of studies to assess the impact of manufacturing activity on the subsurface. Therefore, environmental contamination can be estimated in the laboratory by batch testing, allowing the analysis of kinetics and sorption isotherm. Sorption is often used to evaluate soil retention capacity for a compost and the potential loss via leaching (Wei et al., 2019).

From this perspective, this work evaluates through sorption kinetics and isotherm the 
retention and mobility of the Remazol Black B (RB5) azo dye, which is widely used by the textile industry in the semi arid region of Pernambuco state. For this purpose, two layers of alluvial soil of the dry riverbed of the Capibaribe basin in the mesoregion of the Agreste of Pernmabuco's state will be analyzed.

\section{MATERIALS AND METHODS}

\subsection{Study area}

The studies were conducted in the High Capibaribe region, which embraces the highest portion of the Capibaribe River watershed in the state of Pernambuco. Soil samples were collected at the coordinates $7^{\circ} 566^{\prime} 57.6^{\prime \prime} \mathrm{S}$ and $36^{\circ} 17^{\prime} 57.2^{\prime \prime} \mathrm{W}$ in the dry riverbed, in the portion between the municipalities of Santa Cruz do Capibaribe and Brejo da Madre de Deus.

Soil samples were collected from the first two soil layers with Layer 1 (CM 1) presenting a maximum thickness of $52 \mathrm{~cm}$ and Layer 2 (CM 2) dimension ranging between 17 and $81 \mathrm{~cm}$. Subsequently, the particle-size distribution, $\mathrm{pH}$ in water, and Zero Charge Point (ZCP) according to the EMBRAPA (1997) methods were analyzed. The parameters of organic matter

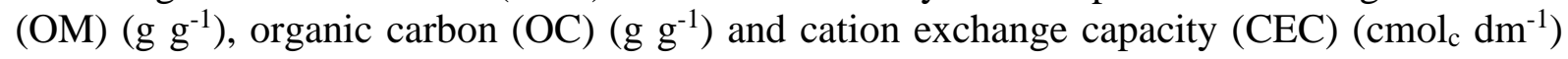
were obtained by analyses of soils already made by Rabelo (2018).

\subsection{Dyes and solutions}

In this study Reactive Black 5 (RB5) dye (Color Index - Reactive Black 5, RB5, $\mathrm{C}_{26} \mathrm{H}_{21} \mathrm{~N}_{5} \mathrm{Na}_{4} \mathrm{O}_{19} \mathrm{~S}_{6}$ ) was chosen as the model dye. $\mathrm{RB} 5$ is a reactive and anionic dye, belonging to the Azo class.

RB5 is identified as a dye popularly used by the textile industry (Felista et al., 2020; El Bouraie and El Din, 2016). Large amounts of RB5 are discharged in the watercourses in developing countries (El Bouraie and El Din, 2016); also, this dye is commonly found in dyebath effluents in higher concentrations than other reactive dyes (Pekakis et al., 2006). Finally, the problem of contamination by RB5 has motivated several studies found in the national literature (Pereira et al., 2019; Cruz Filho et al., 2016; Cruz et al., 2016; Cardoso et al., 2011; Souza et al., 2010).

In order to simulate the actual dyeing process conditions used in the textile industries, the RB5 solution was initially subjected to hydrolysis. In this procedure, the initial $\mathrm{pH}$ of the solution was adjusted to $12.0 \pm 0.05$, with the addition of $20 \%(\mathrm{w} / \mathrm{v})$ sodium hydroxide. Then, the solution was heated for 60 minutes at $80 \pm 2{ }^{\circ} \mathrm{C}$ and stirred on a magnetic stirrer. Subsequently, the solution was cooled to the ambient temperature, and the $\mathrm{pH}$ was adjusted by adding hydrogen sulfide $(0.1 \mathrm{~N})$ to $7.0 \pm 0.05$. Similar hydrolysis procedures were verified in studies developed by Cunico et al. (2015) and Albuquerque et al. (2005).

\subsection{Sorption kinetics}

For the kinetic study, a solution of RB5 at a concentration of $25 \mathrm{mg} \mathrm{L}^{-1}$ was prepared by dissolving $50 \mathrm{mg}$ of RB5 in $2 \mathrm{~L}$ of distilled water. This value is within the dye concentration range for the textile effluent according to El Bouraie and El Din (2016). After the hydrolysis process, the solution was distributed in Erlenmeyers of $100 \mathrm{ml}$ and assuming the soil/solution proportion of 1:10 (5 g of soil to $50 \mathrm{ml}$ of RB5 solution). All samples were prepared in triplicate and stirred at $200 \mathrm{rpm}$ on an orbital shaker for the times of $0.17,0.5,1,3,5,8,10,16,24,48$, and 72 hours.

The experiment was performed at a temperature of $24 \pm 2{ }^{\circ} \mathrm{C}$. In addition, after the samples were removed from the shaker, they were filtered through $0.45 \mu \mathrm{m}$ sterile membrane filters. The quantification of the dye concentration in the samples was evaluated by reading the absorbance at the wavelength identified by the scan $(597 \mathrm{~nm})$ using the Thermo Scientific GENESYS 30 Vis Spectrophotometer.

\section{IPABH}

Rev. Ambient. Água vol. 15 n. 2, e2491 - Taubaté 2020 


\subsection{Sorption Kinetics Modelling}

The results of the kinetic study were adjusted to the Pseudo-first order, Pseudo-second order, and Intra-particle diffusion models.

The Pseudo-first order model is expressed according to Equation 1 (Lagergren, 1898).

$$
q_{t}=q_{e 1}\left(1-e^{-k_{1} t}\right)
$$

Where $q_{e 1}$ and $q_{t}$ are the amounts of dye adsorbed by soil mass $\left(\mathrm{mg} \mathrm{kg}^{-1}\right)$ at equilibrium and by time (h), respectively, and $k_{1}\left(\mathrm{~h}^{-1}\right)$ is the Pseudo-first order constant. 1999).

The Pseudo-second order model is expressed according to Equation 2 (Ho and Mckay,

$q_{t}=k_{2} q_{e 2}^{2} t+q_{e 2}$

Where $q_{e 2}$ is the amount of dye adsorbed by soil mass $\left(\mathrm{mg} \mathrm{kg}^{-1}\right)$ for the second-order model and $k_{2}\left(\mathrm{~kg} \mathrm{~h}^{-1} \mathrm{mg}^{-1}\right)$ is the constant of the Pseudo-second order model.

The intra-particle diffusion model is expressed according to Equation 3 (Weber and Morris, 1963).

$$
q_{t}=k_{i} t^{\frac{1}{2}}+c
$$

Where $k_{i}\left(\mathrm{mg} \mathrm{kg}^{-1} h^{\frac{1}{2}}\right)$ is the constant of the Intra-particle Diffusion model.

\subsection{Sorption isotherms}

A RB5 solution was prepared at a concentration of $40 \mathrm{mg} \mathrm{L}^{-1}$ to perform the isotherm experiments. After performing the hydrolysis, the concentrations of $10 ; 15 ; 20 ; 25 ; 30 ; 35 \mathrm{mg}$ $\mathrm{L}^{-1}$ were obtained by dissolution. The tests were prepared in triplicate, maintaining the proportion of $5 \mathrm{~g}$ of soil to $50 \mathrm{ml}$ of solution used in the kinetics. All samples were stirred at $200 \mathrm{rpm}$ on an orbital shaker until the equilibrium time determined in the kinetics was reached. Afterward, they were filtered with $0.45 \mu \mathrm{m}$ sterile membrane filters and the dye concentrations in the samples were determined by absorbance measurement.

\subsection{Sorption Isotherms Modelling}

Sorption isotherms were adjusted to the linear and nonlinear Freundlich models. At ambient concentrations, the sorption isotherm of organic pollutants in the soil can often be considered linear and represented by Equation 4 (Martins and Mermoud, 1999).

$q_{e}=k_{D} C_{e}$

Where $C_{e}$ is the RB5 concentration in the solution $\left(\mathrm{mg} \mathrm{L}^{-1}\right)$ and $k_{D}$ is the distribution coefficient for the linear model $\left(\mathrm{L} \mathrm{kg}^{-1}\right)$.

Freundlich adsorption isotherm considers the surface heterogeneity and assumes that sorption occurs at sites with different sorption energies, being expressed in the nonlinear form according to Equation 5 (Freundlich and Heller, 1939).

$q_{e}=K_{F} C_{e^{\frac{1}{n}}}$

Where $K_{F}$ is the Freundlich constant $\left(\mathrm{L} \mathrm{kg}^{-1}\right)$ and $\mathrm{n}$ is the affinity coefficient $\left(\mathrm{kg} \mathrm{L}^{-1}\right)$.

A considerable portion of organic compounds sorption in soils is attributed to the organic 
content of the matrix. Therefore, it is essential to investigate the normalized sorption coefficient of the organic carbon $\left(K_{O C}\right)$, which is expressed by Equation 6 .

$$
K_{O C}=\frac{k_{w}}{f c o}
$$

Where $k_{w}$ is the soil partition coefficient and $f c o$ is the fraction of the soil organic content. Therefore, the lower the $K_{o c}$ value is, the higher the concentration of the compound in solution is and higher values indicate a tendency for chemical substances to be sorbed by the soil particles (Gavrilescu, 2005).

\section{RESULTS AND DISCUSSION}

\subsection{Soil characterization}

The results of the analyses for the soils are shown in Table 1. For granulometric analysis, the test was performed in duplicate, while PH and ZCP were performed in triplicate, the respective standard deviations are presented.

Table 1. Main characteristics of the analyzed soils.

\begin{tabular}{|c|c|c|c|c|c|c|c|c|}
\hline Layer & Sand \% & Silt \% & Clay \% & $\mathrm{pH}$ in water & $\mathbf{Z C P}$ & $\begin{array}{l}\mathrm{OM}^{*} \\
\left(\mathrm{~g} \mathrm{~g}^{-1}\right)\end{array}$ & $\begin{array}{c}O C^{*} \\
\left(\mathrm{~g} \mathrm{~g}^{-1}\right)\end{array}$ & $\begin{array}{c}\mathrm{CEC}^{*} \\
\left(\mathrm{cmolc} \mathrm{dm}^{-3}\right)\end{array}$ \\
\hline \multirow{2}{*}{ CM 1} & $79.395 \pm 0.35$ & $15.71 \pm 0.20$ & $4.895 \pm 0.35$ & \multirow{2}{*}{$8.26 \pm 0.28$} & \multirow{2}{*}{$5.50 \pm 0.20$} & \multirow{2}{*}{$2.17 \%$} & \multirow{2}{*}{$1.26 \%$} & \multirow{2}{*}{7.4} \\
\hline & & Loamy sand & & & & & & \\
\hline \multirow{2}{*}{ CM 2} & $95.48 \pm 0.40$ & $4.205 \pm 0.35$ & $0.315 \pm 0.29$ & \multirow{2}{*}{$6.01 \pm 0.35$} & \multirow{2}{*}{$6.00 \pm 0.35$} & \multirow{2}{*}{$1.67 \%$} & \multirow{2}{*}{$0.97 \%$} & \multirow{2}{*}{3.3} \\
\hline & & Sand & & & & & & \\
\hline
\end{tabular}

* Rabelo (2018)

\pm standard deviation.

\subsection{Sorption Kinetics}

The kinetic study shows that CM 2 (Sand) reaches equilibrium time for RB5 sorption faster than CM 1 (Loamy Sand). Layers CM 1 and CM 2 achieved equilibrium at 16 and 10 hours, respectively, and the maximum sorption was $81.81 \mathrm{mg} \mathrm{kg}^{-1}$ for $\mathrm{CM} 1$ and $21.7 \mathrm{mg} \mathrm{kg}^{-1}$ for CM 2.

Alexandre (2019), analyzed the sorption of Direct Black 22 dye for the same soils of this study, finding an equilibrium time of 8 and 4 hours for CM 1 and CM 2, respectively. The first layer adsorbed $122 \mathrm{mg} \mathrm{kg}^{-1}$, while the amount adsorbed in the second layer was $40 \mathrm{mg} \mathrm{kg}^{-1}$. Therefore, these data corroborate with the present study regarding the higher sorption capacity of CM 1.

The anionic or cationic nature of dyes can be used as the first parameter to understand the mechanisms involved in the sorption process of these compounds in soils. Depending on the soil $\mathrm{pH}$, anionic dyes may bind to non-specific anion exchange sites such as Iron and Aluminum oxides (Ketelsen and Meyer-Windel, 1999). On the one hand, when pH is lower than ZCP, the matrix has a positively charged surface. On the other hand, if the matrix has a $\mathrm{pH}$ higher than ZCP, the surface is negatively charged (Dawodu and Akpomie, 2016; Bachratá et al., 2013). Positively charged surfaces favor the sorption of anionic species, while negatively charged surfaces favor the sorption of cationic species (Dawodu and Akpomie, 2016).

In this sense, analyzing the sorption of Acid Yellow 23 dye in soils, Dawodu and Akpomie (2016) highlighted that due to the anionic nature of the dye, it will be attracted by a positively charged adsorbent surface, being the sorption optimal for $\mathrm{pH}$ lower than the ZCP of the soil, which was 5.8 . 
The $\mathrm{pH}$ of $\mathrm{CM} 1$ is higher than the ZCP value, and for CM 2, the value is approximately equal, indicating that the analyzed soils have a low retention potential for the anionic RB5.

The experimental data of the kinetic study with the corresponding adjustments to Pseudofirst order, Pseudo-second order and Intra-particle diffusion models for CM 1 (Figure 1 a) and CM 2 (Figure 1 b) can be seen in Figure 1. First, there is a rapid increase in sorption, which is followed by a slow rise until equilibrium is achieved, indicating the amount for which the adsorbed dye remains approximately constant.

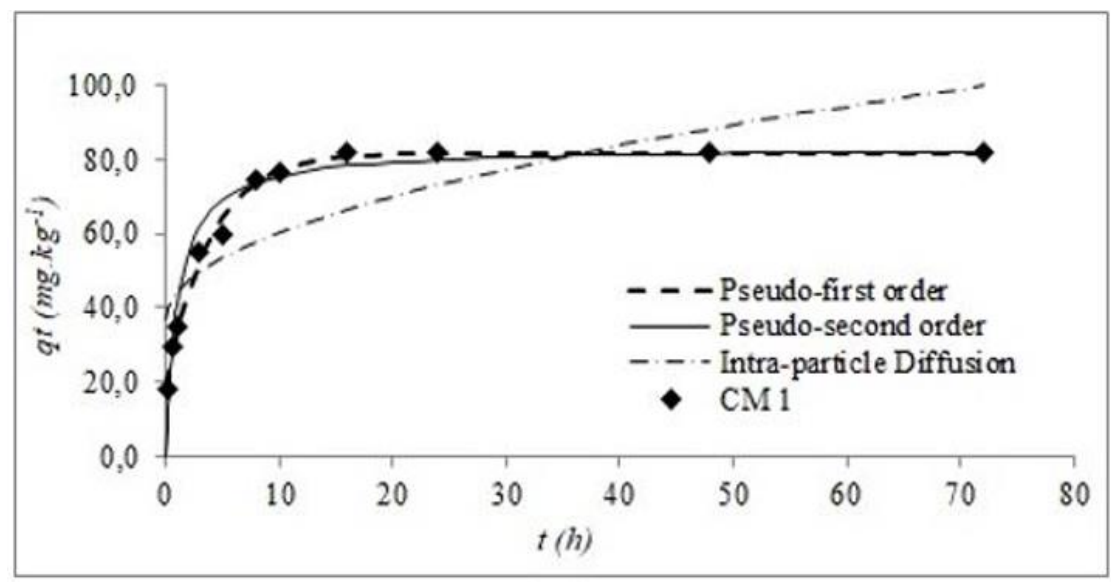

(a)

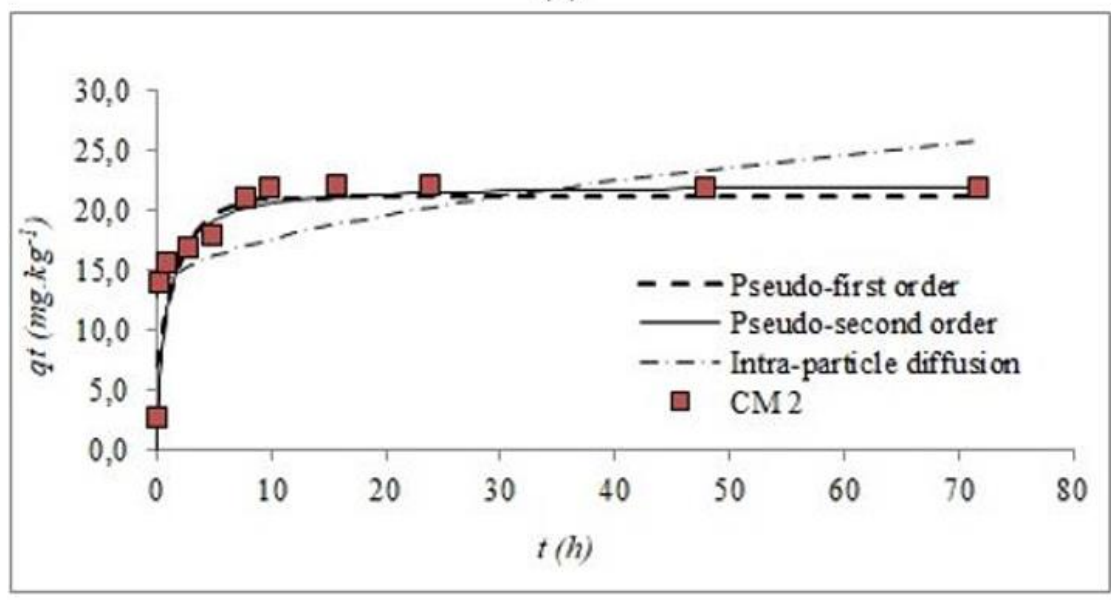

(b)

Figure 1. Kinetics studies and adjustments for the Pseudo-first order, Pseudo-second order and Intra-particle diffusion models for CM 1 (a) and CM 2 (b).

The parameters concerning the adjustments of Pseudo-first order, Pseudo-second order, and Intra-particle diffusion are displayed in Table 2.

Both Pseudo-first order and Pseudo-second order models describe well the experimental data for both soil layers. However, $\mathrm{q}_{\mathrm{e} 1}$ and $\mathrm{q}_{\mathrm{e} 2}$ estimated values, which were similar to the real ones, and the determination coefficients $\left(\mathrm{R}^{2}\right)$, which are near to one, showed best adjustments to the Pseudo-second order model. Studying the sorption of the anionic dye Acid Yellow 23 in a Nigerian soil, Dawodu and Akpomie (2016) also found a good fit for the Pseudo-first order $\left(\mathrm{R}^{2}=0.977\right)$ and Pseudo-second order $\left(\mathrm{R}^{2}=0.978\right)$ models, indicating the occurrence of several simultaneous processes that are involved in sorption. In the Pseudo-second order model, chemisorption is the rate-limiting step and sorption capacity is proportional to the number of active sites occupied on the sorbent (Ho and Mckay, 1999). For intra-particle diffusion model, 
it is observed that the lines do not pass through the origin, indicating that the intra-particle diffusion is not the only mechanism controlling the adsorption rate (Jiang et al., 2019), which is also confirmed by the low determination coefficient for both soil layers.

Table 2. Kinetics parameters for RB5 sorption for CM 1 and CM 2.

\begin{tabular}{lccc}
\hline Model & Parameter & CM 1 & CM 2 \\
\hline \multirow{3}{*}{ Pseudo-first order model } & $k_{l}\left(\mathrm{~h}^{-1}\right)$ & 1.1244 & 3.6515 \\
& $q_{e l}\left(\mathrm{mg} \mathrm{kg}^{-1}\right)$ & 78.5674 & 20.5762 \\
& $\mathrm{R}^{2}$ & 0.9886 & 0.9892 \\
\hline \multirow{3}{*}{ Pseudo-second order model } & $k_{2}\left(\mathrm{~kg} \mathrm{~h}^{-1} \mathrm{mg}^{-1}\right)$ & 0.0116 & 0.0792 \\
& $q_{e 2}\left(\mathrm{mg} \mathrm{kg}^{-1}\right)$ & 83.4193 & 21.9957 \\
& $\mathrm{R}^{2}$ & 0.9997 & 0.9998 \\
\hline \multirow{2}{*}{ Intra-particle diffusion } & $k_{i}\left(\mathrm{mg} \mathrm{kg}^{-1} h^{\frac{1}{2}}\right)$ & 7.4206 & 1.5372 \\
& $\mathrm{R}^{2}$ & 0.9572 & 0.9525 \\
\hline
\end{tabular}

The applicability of the Pseudo-second order model to describe RB5 sorption kinetics in both soils is validated by the linearity, as shown in Figure 2 through the plotted graph of t/qt values versus time.

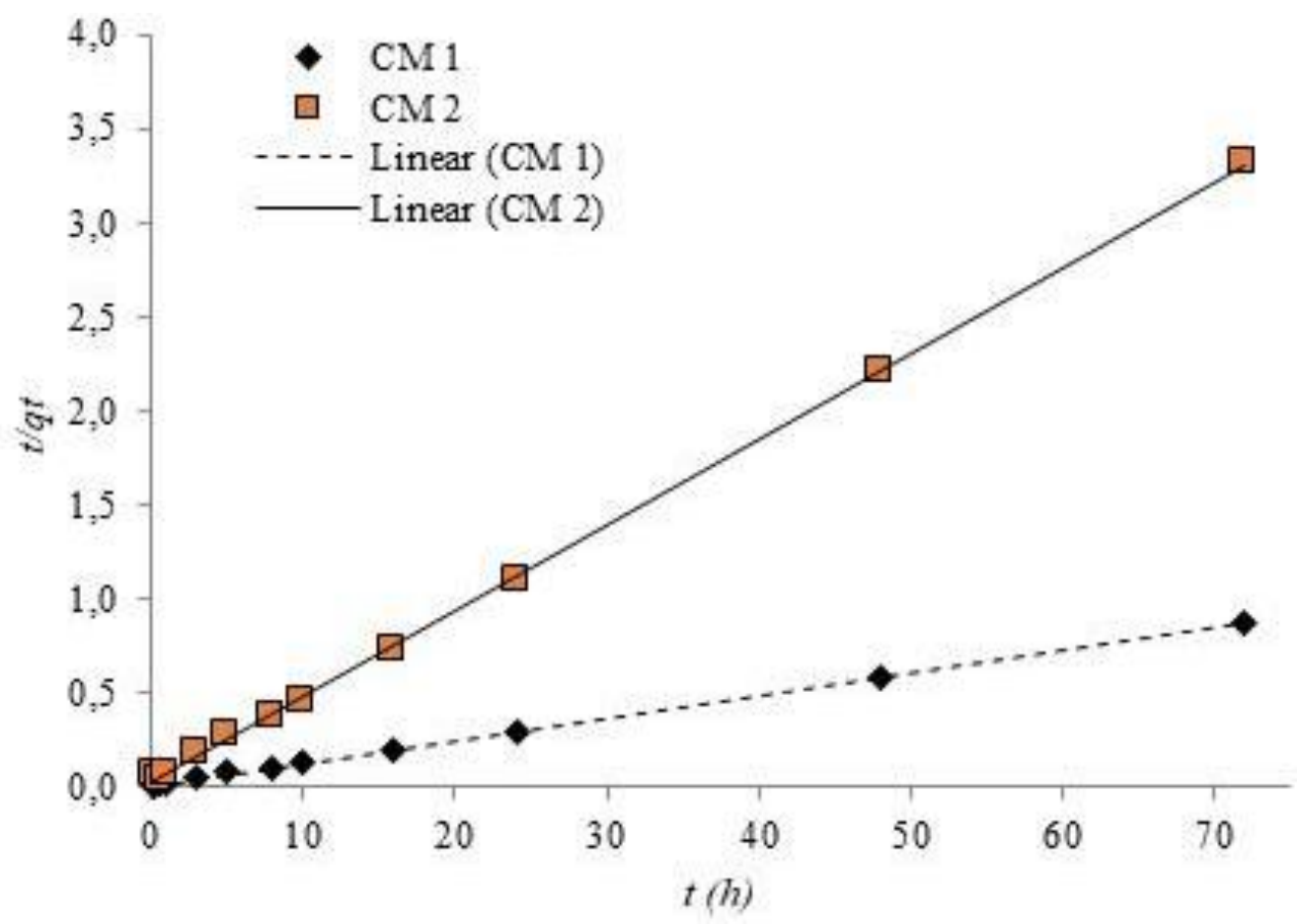

Figure 2. Adjustment to the Pseudo-second order model for CM 1 and CM 2.

\subsection{Sorption Isotherms}

The parameters for the linear and nonlinear modeling are shown in Table 3. It was observed that the RB5 sorption isotherms for both soil layers were nonlinear, and they were satisfactorily described by the Freundlich model $\left(\mathrm{R}^{2}>0.9\right)$.

Freundlich isotherms model also satisfactorily described the sorption of Thioflavin dye in sediments taken from the banks of the Váh River, in Šal'a city, Slovak Republic (Bachratá et al., 2013), and of Basic Yellow X-5GL, Basic Red 13, Direct Blue 86, Vat Yellow 2 and Mordant Black 11 dyes in sediments from the Qinghe River (Liu et al., 2001). Other studies 
also reported a good correlation of the Freundlich equation with experimental data of dye sorption in soils, such as the Acid Yellow 23 (Dawodu and Akpomie, 2016), Basic Blue 9 (Sana and Jalila, 2016), Congo Red (Smaranda et al., 2011), and Acid Red 14 dye (Qu et al., 2008).

Table 3. RB5 Sorption parameters for the linear and Freundlich models.

\begin{tabular}{lccc}
\hline Model & Parameter & CM 1 & CM 2 \\
\hline \multirow{2}{*}{ Linear } & $k_{D}\left(\mathrm{~L} \mathrm{~kg}^{-1}\right)$ & 5.2867 & 0.9996 \\
& $\mathrm{R}^{2}$ & 0.9478 & 0.9082 \\
\hline \multirow{3}{*}{ Freundlich } & $K_{F}\left(\mathrm{~L} \mathrm{~kg}^{-1}\right)$ & 8.6407 & 0.1868 \\
& $\mathrm{R}^{2}$ & 0.9970 & 0.9962 \\
& $n\left(\mathrm{~kg} \mathrm{~L}^{-1}\right)$ & 1.1959 & 0.6659 \\
\hline
\end{tabular}

The results presented for both $\mathrm{k}_{\mathrm{D}}$ and $\mathrm{K}_{\mathrm{F}}$ confirm a more significant interaction of RB5 solution with CM 1 than with CM 2. These parameters are used to estimate the degree of pollutants sorption in soils. Therefore, higher values, such as that verified for CM 1, indicate a higher tendency of sorption in the solid matrix, and smaller values, such as CM 2, imply weaker interactions between the dye and the matrix, resulting in greater mobility. The coefficient $n$ for CM 1 indicates sorption closer to the linear.

The results of $K_{F}$ enabled the determination of $K_{o c}$, obtaining values of 685.8 and $19.2 \mathrm{~L}$ $\mathrm{kg}^{-1}$ for CM 1 and CM 2, respectively. These values indicate for CM 1 a higher tendency of these particles being sorbed by the soil. The inverse effect is verified for CM 2, for which the Koc value implies a higher susceptibility to leaching losses.

The graphs corresponding to Freundlich model adjustments for CM 1 and CM 2 are shown in Figure 3.

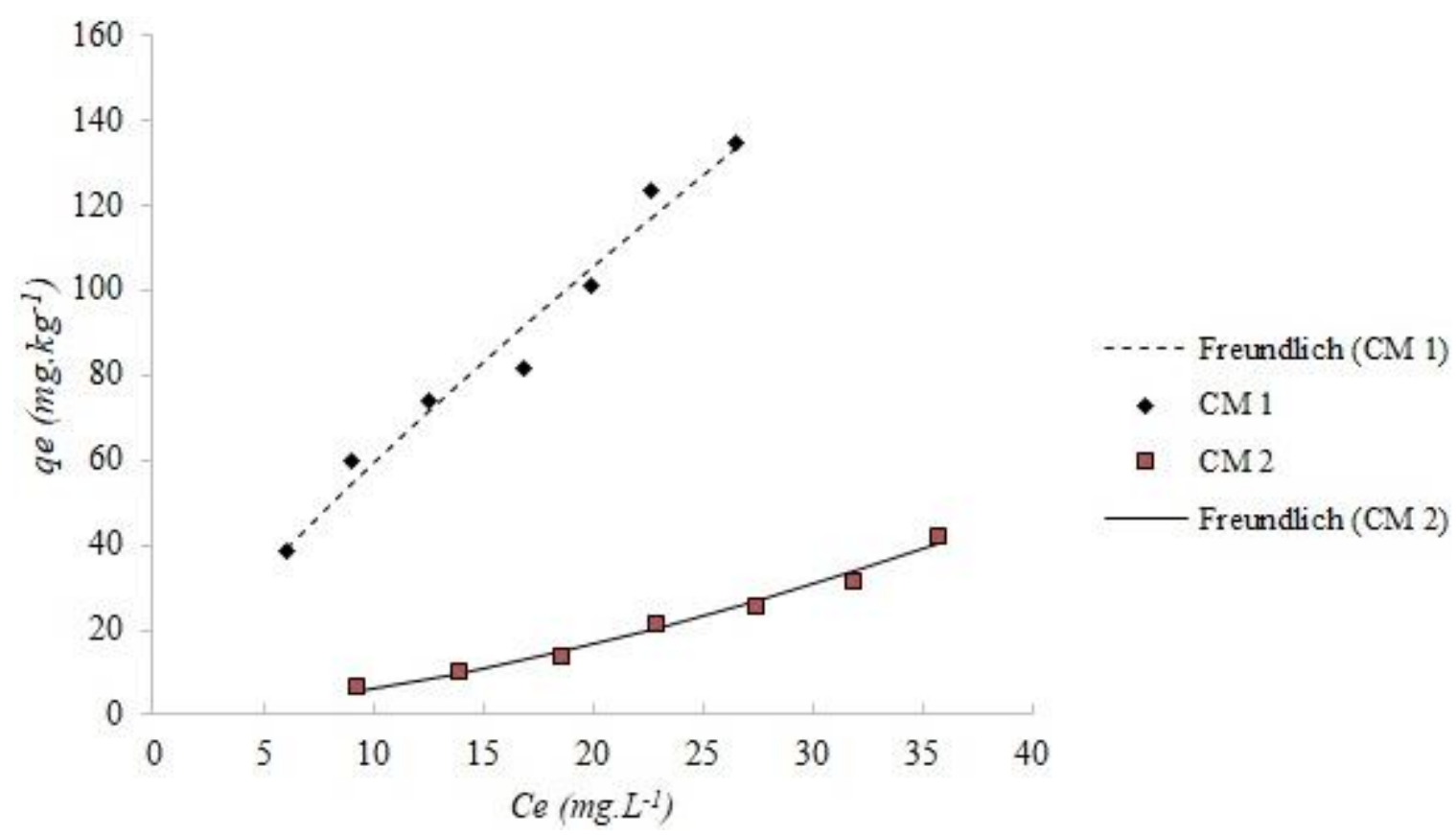

Figure 3. Freundlich isotherms for CM 1 and CM 2.

Considering the chemical composition of the sediment, it can be stated that its organic and inorganic components will significantly affect the sorption capacity (Bachratá et al., 2013). Regarding the organic component, Liu et al. (2001) verified a decrease in sorption of the anionic 
dyes Mordant Black 11 and Direct Blue 86 (25\% and 40\%, respectively), in a fluvial soil after $\mathrm{OC}$ removal by $\mathrm{H}_{2} \mathrm{O}_{2}$ treatment. Therefore, the higher content of this component in $\mathrm{CM} 1$ than in CM 2 (1.26\% and $0.97 \%$ of OC for CM 1 and CM 2, respectively) and the respective maximum sorption capacities indicate the influence of soil organic component on RB5 sorption.

Besides the organic content, the dye molecules, in general, have a strong affinity with clay minerals. The clay fraction of the soils was identified as predominant in the sorption of the Bright Blue anionic dyes (Ketelsen and Meyer-Windel, 1999) and RB5 (Lazaridis and Keenan, 2010). Lazaridis and Keenan (2010) analyzed the sand, silt, and clay fractions before and after RB5 sorption and they found that only the clay fraction showed a significant displacement in its absorbance peak. Therefore, suggesting that no considerable sorption phenomenon occurred for silt and sand fractions (Lazaridis and Keenan, 2010).

For cationic dyes, it is expected a more significant interaction with the clay content than for the anionic dyes such as RB5. In this sense, in the sorption of three dyes in clays, Elmoubarki et al. (2015) found a higher sorption capacity for cationic dyes Methylene Blue and Malachite Green than for anionic dye Methyl Orange. This is because clay has a higher capacity for cation exchange than for anion exchange due to its negatively charged layers (Errais et al., 2012). However, the presence of kaolinite with acid surfaces favors the sorption of anionic dyes because these minerals are the main adsorbent sites for these dyes (Errais et al., 2012). Consequently, the higher retention of RB5 was verified for CM 1 and is correlated to the clay content in soils (clay content of $4.895 \%$ for CM 1 and $0.315 \%$ for CM 2).

\section{CONCLUSIONS}

Sorption kinetics was best described by the Pseudo-second order model. The kinetic sorption rates show the influence of soil characteristics, such as organic content and clay content, on the RB5 sorption process.

This difference in sorption capacity for soils demonstrates the importance of studying the soil as a heterogeneous medium, in which there are different behaviors of contaminants' dissipation.

The isotherms had a nonlinear behavior for both soil layers, with the experimental data satisfactorily adjusted to the Freundlich model. The isotherm parameters confirmed a more significant interaction of RB5 with the loamy sand layer (CM 1) than with the sand layer (CM 2), indicating a lower leaching capability in the upper layer than in the lower layer, which is more mobile for RB5 contamination.

\section{ACKNOWLEDGMENTS}

This work was carried out with the support of the project "Transfer of Water and Mixtures of Reactive Pollutants in Anthropized Soils" (CNPq process No. 436875/2018-7) and of the Foundation for the Support of Science and Technology of the State of Pernambuco (FACEPE/CAPES process IBPG-0125-3.01/17), and by project "National Observatory of Water and Carbon Dynamics in the Caatinga Biome ONDACBC $\left(\mathrm{CNPq}\right.$ process $\mathrm{N}^{\circ}$ 465764/2014-2; CAPES process $\mathrm{N}^{\circ}$ 88887.136369/2017-00; FACEPE process APQ-0498$3.07 / 17)$.

\section{REFERENCES}

ALBUQUERQUE, M. G. E.; LOPES, A. T.; SERRALHEIRO, M. L.; NOVAIS, J. M.; PINHEIRO, H. M. Biological sulphate reduction and redox mediator effects on azo dye decolourisation in anaerobic-aerobic sequencing batch reactors. Enzyme And Microbial Technology, v. 36, n. 5-6, 2005. https://doi.org/10.1016/j.enzmictec.2005.01.005 
ALEXANDRE, J. I. da S. Análise da sorção do corante DB22 em solo aluvionar para Compor um sistema alagado construído. 2019. 102f. Dissertação (Mestrado em Engenharia Civil e Ambiental) - Universidade Federal de Pernambuco, Recife, 2019.

BACHRATÁ, M.; ŠUŇOVSKÁ, A.; HORNÍK, M.; PIPÍŠKA, M.; AUGUSTÍN, J. Sorption of Synthetic Dyes Onto River Sediments: A Laboratory Study. Nova Biotechnologica et Chimica, v. 12, n. 1, 2013.

BRAGA, R. A. P. As águas invisíveis nos rios intermitentes. In: BRAGA, R. A. P. Águas de areias. Recife: Clã, 2016. p. 11-37.

BRAGA, R. A. P.; FARIAS, C. R. de O.; SILVA, S. R. da; CAVALCANTI, E. R. Gestão e educação socioambiental na Bacia do Capibaribe. Recife: Clã, 2015. 140 p.

CARDOSO, N. F.; PINTO, R. B.; LIMA, E. C.; CALVETE, T.; AMAVISCA, C. V.; ROYER, B.; CUNHA, M. L.; FERNANDES, T. H. M.; PINTO, I. S. Removal of remazol black B textile dye from aqueous solution by adsorption. Desalination, v. 269, n. 1-3, p.92-103, 2011. https://doi.org/10.1016/j.desal.2010.10.047

CRUZ FILHO, I. J. da; FERREIRA, H. K. L.; SILVA, S. K. G. da; MACHADO, S. E. F.; ZAIDAN, L. E. M. C.; LIMA, V. F. de; MARQUES, O. M.; NASCIMENTO JÚNIOR, A. J. do. Otimização do processo de remoção do corante preto de remazol B por uso de biomassa mista de Aspergillus niger van Tieghem, 1867 (Ascomycota: Trichocomaceae) e Pennisetum purpureum Schumach., 1827 (Poales: Poaceae). Revista Brasileira de Gestão Ambiental e Sustentabilidade, v. 3, n. 6, p. 375-384, 2016. http://dx.doi.org/10.21438/rbgas.030611

CRUZ, I. J. da; MARQUES, L. M.; SOUZA, K. C.; LIMA, V. F. de; MARQUES, O. M.; NASCIMENTO JÚNIOR, A. J. do. Remoção do corante Remazol Black b pelo uso da biomassa mista de Aspergillus niger e capim elefante (Pennisetum purpureum schum). Engevista, v. 18, n. 2, p. 265-279, 2016. https://doi.org/10.22409/engevista.v18i2.727

CUNICO, P.; KUMAR, A.; FUNGARO, D. A. Adsorption of Dyes from Simulated Textile Wastewater onto Modified Nanozeolite from Coal Fly Ash. Journal of Nanoscience and Nanoengineering, v. 1, n. 3, 2015.

DAWODU, M. O.; AKPOMIE, K. G. Evaluating the potential of a Nigerian soil as an adsorbent for tartrazine dye: Isotherm, kinetic and thermodynamic studies. Alexandria Engineering Journal, v. 55, n. 4, 2016. https://doi.org/10.1016/j.aej.2016.08.008

EL BOURAIE, M.; EL DIN, W. S. Biodegradation of Reactive Black 5 by Aeromonas hydrophila strain isolated from dye-contaminated textile wastewater. Sustainable Environment Research, v. 26, n. 5, 2016. https://doi.org/10.1016/j.serj.2016.04.014

ELMOUBARKI, R.; MAHJOUBI, F. Z.; TOUNSADI, H.; MOUSTADRAF, J.; ABDENNOUR, M.; ZOUHRI, A.; ALBANI, A. El.; BARKA, N. Adsorption of textile dyes on raw and decanted Moroccan clays: Kinetics, equilibrium and thermodynamics. Water Resources And Industry, v. 9, 2015. https://doi.org/10.1016/j.wri.2014.11.001

EMBRAPA. Manual de Métodos de Análise de Solo. 2. ed. Rio de Janeiro: Embrapa-cnps, 1997. $212 \mathrm{p}$. 
ERRAIS, E.; DUPLAY, J.; ELHABIRI, M.; KHODJA, M.; OCAMPO, R.; BALTENWECKGUYOT, R.; DARRAGI, F. Anionic RR120 dye adsorption onto raw clay: Surface properties and adsorption mechanism. Colloids And Surfaces A: Physicochemical and Engineering Aspects, v. 403, 2012. https://doi.org/10.1016/j.colsurfa.2012.03.057

FELISTA, M. M.; WANYONYI, W. C.; GILBERT, O. Adsorption of Anionic Dye (Reactive Black 5) Using Macadamia Seed Husks: Kinetics and Equilibrium Studies. Scientific African, in press, 2020. https://doi.org/10.1016/j.sciaf.2020.e00283

FREUNDLICH, H.; HELLER, W. The Adsorption ofcis- and trans-Azobenzene. Journal of the American Chemical Society, v. 61, n. 8, 1939.

GAVRILESCU, M. Fate of Pesticides in the Environment and its Bioremediation. Engineering In Life Sciences, v. 5, n. 6, 2005. https://doi.org/10.1002/elsc.200520098

HO, Y. S.; MCKAY, G. Pseudo-second order model for sorption processes. Process Biochemistry, v. 34, n. 5, 1999. https://doi.org/10.1016/S0032-9592(98)00112-5

HUYNH, N.; CHIEN, C. A hybrid multi-subpopulation genetic algorithm for textile batch dyeing scheduling and an empirical study. Computers \& Industrial Engineering, v. 125, 2018. https://doi.org/10.1016/j.cie.2018.01.005

JAYANTHY, V.; GEETHA, R.; RAJENDRAN, R.; PRABHAVATHI, P.; SUNDARAM, S. K.; KUMAR, S, D.; SANTHANAM, P. Phytoremediation of dye contaminated soil by Leucaena leucocephala (subabul) seed and growth assessment of Vigna radiata in the remediated soil. Saudi Journal Of Biological Sciences, v. 21, n. 4, 2014. https://doi.org/10.1016/j.sjbs.2013.12.001

JIANG, S.; YU, T.; XIA, R.; WANG, X.; GAO, M. Realization of super high adsorption capability of $2 \mathrm{D} \delta-\mathrm{MnO} 2 / \mathrm{GO}$ through intra-particle diffusion. Materials Chemistry and Physics, v. 232, p.374-381, 2019. https://doi.org/10.1016/j.matchemphys.2019.05.004

KETELSEN, H.; MEYER-WINDEL, S. Adsorption of brilliant blue FCF by soils. Geoderma, v. 90, n. 1-2, 1999. https://doi.org/10.1016/S0016-7061(98)00119-0

KHARAT, D. S. Treatment of textile industry effluents: limitations and scope. Journal of Environmental Research and Development, v. 9, n. 4, 2015.

LAGERGREN, S. About the theory of so-called adsorption dissolved substances. Kungliga Svenska Vetenskapsakademiens Handlingar, v. 24, n. 4, 1898.

LAZARIDIS, N. K.; KEENAN, H. E. Chitosan beads as barriers to the transport of azo dye in soil columns. Journal of Hazardous Materials, v. 173, n. 1-3, 2010. https://doi.org/10.1016/j.jhazmat.2009.08.062

LIU, R.; LIU, X.; TANG, H.; SU, Y. Sorption Behavior of Dye Compounds onto Natural Sediment of Qinghe River. Journal of Colloid and Interface Science, v. 239, n. 2, 2001.

MARTINS, J. M. F.; MERMOUD, A. Transport of rimsulfuron and its metabolites in soil columns. Chemosphere, v. 38, n. 3, 1999. https://doi.org/10.1006/jcis.2001.7597

PEKAKIS, P. A.; XEKOUKOULOTAKIS, N. P.; MANTZAVINOS, D. Treatment of textile dyehouse wastewater by $\mathrm{TiO} 2$ photocatalysis. Water Research, v. 40, n. 6, p.1276-1286, 2006. https://doi.org/10.1016/j.watres.2006.01.019 
PEREIRA, L. de O.; MOURA, S. G. de.; COELHO, G. C. M.; OLIVEIRA, L. C. A.; ALMEIDA, E. T. de; MAGALHÃES, F. Magnetic photocatalysts from industrial residues and $\mathrm{TiO} 2$ for the degradation of organic contaminants. Journal of $\begin{array}{llllllll}\text { Environmental Chemical Engineering, } & \text { v. 7, n. 1, } & \text { p.1-12, } 2019 .\end{array}$ https://doi.org/10.1016/j.jece.2018.102826

QU, B.; ZHOU, J.; XIANG, X.; ZHENG, C.; ZHAO, H.; ZHOU X. Adsorption behavior of Azo Dye C. I. Acid Red 14 in aqueous solution on surface soils. Journal of Environmental Sciences, v. 20, n. 6, 2008. https://doi.org/10.1016/S10010742(08)62116-6

RABELO, A. E. C. G. C. Retenção e mobilidade da sulfadiazina em um aluvionar do Alto do Capibaribe. 2018. 76 p. Dissertação (Mestrado em Tecnologias Energéticas e Nucleares) - Universidade Federal de Pernambuco, Recife, 2018.

SANA, D.; JALILA, S. Combined effect of unsaturated soil condition and soil heterogeneity on methylene blue adsorption/desorption and transport in fixed bed column: Experimental and modeling analysis. Journal of King Saud University - Science, v. 28, n. 4, 2016. https://doi.org/10.1016/j.jksus.2016.01.004

SEBRAE. Estudo econômico do arranjo produtivo local de confecções do Agreste Pernambucano. Recife, 2013. 151 p.

SHALABY, N. H.; EWAIS, E. M. M.; ELSAADANY, R. M; AHMED, A. Rice husk templated water treatment sludge as low cost dye and metal adsorbent. Egyptian Journal of Petroleum, v. 26, n. 3, 2017. https://doi.org/10.1016/j.ejpe.2016.10.006

SMARANDA, C.; GAVRILESCU, M.; BULGARIU, D. Studies on Sorption of Congo Red from Aqueous Solution onto Soil. International Journal of Environmental Research, v. 5, n. 1, 2011. https://dx.doi.org/10.22059/ijer.2010.303

SMARANDA, C.; POPESCU, M. C.; BULGARIU, D.; MĂLUȚAN, T.; GAVRILESCU, M. Adsorption of organic pollutants onto a Romanian soil: Column dynamics and transport. Process Safety and Environmental Protection, v. 108, 2017. https://doi.org/10.1016/j.psep.2016.06.027

SOUZA, S. M. de A. G. U. de; BONILLA, K. A. S.; SOUZA, A. A. U. de. Removal of COD and color from hydrolyzed textile azo dye by combined ozonation and biological treatment. Journal of Hazardous Materials, v. 179, n. 1-3, p. 35-42, 2010. https://doi.org/10.1016/j.jhazmat.2010.02.053

STAGNARO, S. M.; VOLZONE, C.; HUCK, L. Nanoclay as Adsorbent: Evaluation for Removing Dyes Used in the Textile Industry. Procedia Materials Science, v. 8, 2015. https://doi.org/10.1016/j.mspro.2015.04.112

WEBER, W. J.; MORRIS, J. C. Kinetics of adsorption on carbon from solution. Journal of Sanitary Engineering, Division ASCE, v. 89, n. 2, 1963.

WEI, Z.; YAN, X.; LU, Z.; WU, J. Phosphorus sorption characteristics and related properties in urban soils in southeast China. Catena, v. 175, 2019. https://doi.org/10.1016/j.catena.2018.12.034 